\title{
Assault on the Public Good
}

\author{
Enver Motala \\ https://orcid.org/0000-0002-7999-9720 \\ Research Associate, Centre for Education Rights and Transformation, \\ University of Johannesburg, South Africa \\ emotala1@gmail.com
}

The struggles around \#FMF (FeesMustFall) have come to haunt us anew as the unrequited ghosts of public policy failure following the events of 2015-2016. This is hardly surprising because, as we predicted then, these issues will not go away unless there is the courage and the will to resolve them properly by making the appropriate political and policy choices.

I was asked to speak to this issue at the invitation of IFAA (the Institute for African Alternatives) in March of this year (2021) and this Commentary is based on what I said at the time. I argued that there were essentially two approaches to the question of universal free quality higher education for all (free higher education henceforth), even given some variations within them.

There are those who are either against or sceptical about funding free higher education for all and those who think it is eminently possible to do so. There is a considerable body of scholarship to support the argument I make though for obvious reasons I do not reference these here.

To begin with, I would characterise the perspective that opposes the ideas and practice of free higher education as a reactionary position marked by its a-historicism, pragmatism and conservatism. The opposing approach, which is supportive of free higher education, I argue is historically contextual, seeks a radical alternative to what prevails in public policy and is fundamentally transformative. These differences were already in evidence around the 2015-2016 \#FMF struggles but have been accentuated by the COVID-19 pandemic and the policy responses to it. I deal with each of these approaches in turn.

The position that I regard as a-historical, pragmatist and conservative is a-historical in several senses.

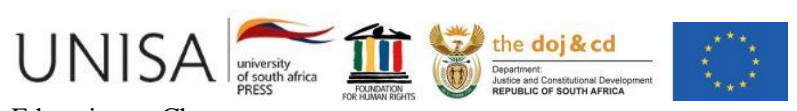

Education as Change

https://upjournals.co.za/index.php/EAC

Volume 25 | 2021 | \#9305 | 6 pages

https://doi.org/10.25159/1947-9417/9305 ISSN 1947-9417 (Online)

(C) The Author(s) 2021 
1. Despite claims to the contrary in policy-speak, it takes little account of South African history because it ignores that the claims for access to higher education are very much a part of the right to reclamation arising from that destructive history. Despite all the proclamations about the "legacy of apartheid", the deep historical impact of flagrantly racist and exploitative practices and the extraordinary burden of an oppressive system of social reproduction on women and rural communities are ignored. Apartheid capitalism's edifice was built in the first place on conquest, the forcible eviction of millions from their ancestral lands and a forced labour regime that stripped the indigenous people of Southern Africa of every meaningful right while at the same time converting especially women and families into vassals whose role was simply to reproduce the labour force, propelled against its will into capitalist labour. The negation of the right to quality higher education - indeed all quality education — was intrinsic to such a regime and makes the right to education at all levels fundamental to historical redress and the dignity of a scorned people. Unless this is recognised in practice, the provision of education will remain qualitatively and socially indistinguishable from the "fundamentalist" dogma promoted by the architects of racist education.

2. During the \#FMF struggles of 2015-2016, some commentators opposed the claims to free higher education, arguing that what had happened in the postcolonial history of African (and other) countries represents failed attempts by post-colonial governments for the massification and expansion of higher education. This view could simply be dismissed as historical amnesia if it were not so patently subservient to the agenda of particular global interests. It's ahistoricism lies in the deliberate obfuscation of the impact of the structural adjustment policies of what Williamson termed the "Washington consensus" (Hurt 2020) imposed on the development of African states. There is evidence aplenty of the deleterious effects of these policies and the programmes they enforced on African education systems and on public services more generally. Dependency, structural weaknesses and a litany of other negative effects have followed the imperialist dirigisme of these policies.

3. This perspective is also a-historical because it does not refer to the hugely interventionist role some states have played in establishing the minimum conditions for developing social democracies based on welfarist policies as key to their development. These policies were essential to the development of especially European social democracies in the post-war period, resulting in both high levels of economic growth together with policies to support the general welfare of the population, even though these policies were applied differentially because of the class, racialised, gendered and other structural characteristics of these societies. As we know too, these welfare policies are now severely attenuated by the impact of neoliberal policies, as the global pandemic has shown. It goes without saying that these policies were hardly gifted to the populations of those countries but were in fact the direct result of the struggles waged especially by highly organised workers in those countries, pursuant to 
the sacrifices they made against Hitler's fascist plans. It is these public policies that, even though they did not wrest power from the European bourgeoisie, were able to extract social benefits in areas such as health and education, and better wages and living conditions for workers and their families. Even within their limits, these policies constituted huge gains against the established social structures of European society. They included the adoption of policies that made access to higher education (and other welfare benefits) possible for working-class families. The power of these gains extended not only to schooling (whatever its limitations) but also to higher education and to community and worker education programmes, which resulted in the flourishing of working-class cultural institutions. In effect the widest provision of educational and learning opportunities were a sine qua non for the establishment of democratic social systems. Regrettably, these benefits did not extend to European colonies and elsewhere, an issue we do not deal with here, save to say that this too was a consequence of the imposition of imperial policies on developing countries such as South Africa.

4. A-historical accounts of free higher education also fail to recognise that even outside the European social democracies, countries such as Japan, and subsequently many of the East Asian states, adopted similar welfarist policies for their development. More recently China is notable for exactly that and in a country such as South Korea the participation rate in higher education for the relevant age cohort exceeds 90\% - incomparably higher than in South Africa.

5. It is similarly a-historical because the austerity policies to which the South African government is committed, and which have been characterised as "the Treasury view" of fiscal and monetary policy, are derived from the self-same global sources that have dealt differentially with Europe and America while deliberately vitiating the development of Africa, Latin America, Asia and other parts of the world. These global policy regimes favour policies that advance the interests of developed economies and enforce regimes of subservience and dependency on the global South, enthusiastically implemented by local comprador elites. Such regimes have been particularly virulent over the past 70 years through a multiplicity of coercive measures, whether these relate to debt, trade or direct military interventions, to support the ideological agenda and hegemony of corporate capitalism. Do we need to be reminded about the host of wars presently taking place in the Middle East or the unabated American interventions elsewhere ever since the end of World War 2?

\section{It is Pragmatist}

At the IFAA meeting, I argued that the opposition to free higher education is also pragmatist because it accepts uncritically the assumptions of the neoliberal austerity approach to public policy having accepted the refrain that "there is no alternative".

The refusal to contemplate an alternative is in fact an acceptance of the raft of prevailing policies that bear the stamp of what Klein (2008) has called "disaster capitalism" in 
describing corporate profit making and the political and social crises aided by the power of right-wing governments. Pragmatists ignore the impact of the prevailing global policy regimes that privilege unfettered market mechanisms and private gain, opening the door to "user-pays" approaches to the provision of services to the citizenry, and the wholesale opening of opportunities for profit making. One can literally hear the elation emanating from private boardrooms at the prospect of making money from educationrelated loans proposed by self-styled educationists who are openly purveying private interests.

I understand only too well, having been assailed by such charges, that those who support the claims to free higher education are simply naïve for refusing to accept the pragmatic "solutions" within the established framework of policies. This alleged naivete is associated with "left-wing ideas", which have "no practical use", and, even more stridently, is laced with derisive criticisms about its "ideological positions". The source of these criticisms lies in the risible claims to "objectivity"-as if pragmatic ideas are unaffected by any ideological proclivities.

The criticisms against free education for all represent not only a failure of the political and social imagination but also an abandonment of the intellect. It is unremittingly subservient to the given framework of social relations, which it regards as unassailable. The ostensibly "pragmatic" approaches serve only the predilections of conservative approaches, glossing over but in reality deepening existing relations of power and inequality and the status quo. The alternatives proposed are about setting a conceptual framework around which practical possibilities can be built. They are not about the "seizure of power" but about the mobilisation of public and democratic accountability as a minimum condition for transformation. They provide a framework for thinking more rigorously, philosophically and politically about universal free education as a constitutive condition for democracy and the public good.

\section{It is Conservative}

I argued that the orientation of the opponents of free higher education is conservative because its underlying premises can be traced to the economic orthodoxy of the leading schools of anti-progressive economic ideas, using the pandemic as a convenient excuse for its orthodoxy while extending the power of global corporate elites, regardless of its human and planetary consequences. In effect such orthodoxy supports socially regressive government policies purveyed both by the corporate media industry and by what is dominant in academic teaching. The latter is uncritically promoted by faculty in the great majority of higher education institutions worldwide - even though this preponderance is now under serious examination in many places.

Even more alarming is the failure of some leaders in academia who appear to be resistant to the idea of robust intellectual and scholarly, public and community-based engagements for examining the underlying causes of the conflict around free higher education. Instead they have resorted either to short-term administrative measures that 
not only compromise the qualitative integrity of their institutions in a host of ways but also promote ideas that rely on provocative regimes of law and order to deal with the predictable consequences of policy failure - and all of this, while making declaratory statements about the need for transformation associated with a humanist axiology.

\section{What is the Alternative?}

As an alternative to the above perspective, I argued that it is possible to view the crisis regarding free higher education from a vantage point that is contextually historical, seeks a radical alternative, and is directed at achieving goals that are fundamentally transformative.

This approach requires a commitment, in the first place, to an alternative vision-not only for higher education but for society more generally. The conservative policies of government affect not only higher education but also its parallels expressed in the wider contradictions affecting social policy. A wider vision for social policy is required, which must be framed, moreover, within a socio-ecological framework since the problems bequeathed to society are self-evidently of a global and planetary nature. Their resolution cannot be contemplated without recognising the destructive effects of the dominant ideologies not only on higher education but on society and the ecological environment more generally. We simply must reject the paralysis induced by the purveyors of the idea that there can be no alternative to the Thatcherite market ideologies of neoliberalism and austerity.

A critique of this ideology is historically necessary to promote the minimum conditions for the promotion of genuine democratic policy in which socio-economic, ecological, cultural and political claims are intrinsic to the restoration of the dignity of human beings within an ecologically stable environment. Such minimum conditions lay the framework for an alternative point of departure about fiscal, monetary or any other policy affecting human affairs. It requires us to persistently re-examine the exact nature of the society in which we want to live and promote how we might achieve the goals of a humanist democracy and ecologically enduring culture; who indeed are the main constituencies of such a democracy, and what is the quality of their citizenship if they are not to be regarded as no more than the subjects of a state with no substantive and defensible rights, hopes, and aspirations as planetary beings?

Perhaps the most immediate goal of such a re-examination has to do with policies and practices that are the minima for dealing with the structural inequalities that are globally rampant. In South Africa, unenviably one of the most unequal countries on earth, this would immediately refer to the ownership and control of wealth and incomes of which land is the immediate symbol, though it encompasses nearly every arena of wealth, capital and human capability. It is here that the essential aspects of redistributive justice must be conceptualised and practised. 
In this regard, we are fortunate to have an existing body of scholarly, and socially conscious, heterodox and radical political economists and social theorists not imbued with the asphyxiating premises of orthodoxy. For some time now these thinkers have been promoting an alternative socio-historical vision that lies within our grasp, but which has predictably been ignored even while it is supported by social movements and organisations.

Unless the issue of inequality is dealt with in fundamental ways, beyond the vacuous perspectives of liberal constitutionalists who rarely, if ever, point to unfettered power, accumulation and greed as the generative sources of inequality, little meaningful change will be achieved. Constitutions too are an expression of the social organisation of power and remain, as so much literature on the subject has shown, no more than "paper instruments". They are often used to obfuscate the fact that the power yielded to greed and private capital accumulation insidiously undermines the best intentions of constitutions. Unequal power is the ultimate arbiter defying the possibility of meaningful freedom and justice against the blight of unaccountability and privilege. If that is not removed, we have nothing to look forward to but a tryst with barbarism.

The likelihood of achieving the ends of a progressive or radical vision is extremely remote if one continues to privilege extant forms of socio-political agency. Nothing will change if one leaves decision-making about global issues to small cliques of unconscionable corporate executives with the power to use their corrupting leverage to influence the policies of government. In the present arrangement of power and social relations there is, in my view, not an iota of real possibility for meaningful change despite all the promises about "transformation", promises which, repeated ad nauseam, now exude the unmistakable stench of hypocrisy.

For change to occur, it behoves all those who ascribe to progressive ideas to promote much higher levels of public mobilisation and support for social movements together with student organisations, which are often tidally ephemeral, to bring greater public will and choice into the contestations around unaccountable privilege. In this regard, institutions of learning, academics and leaders in them, have an inescapable duty that cannot be "contracted out" to any other source. It speaks to their calling and social commitment, their intellectual responsibility and public duty and should reflect the essence of their being. Alternatives exist in history and these must find their place in the public imagination and its discussions, arguments, reflections and ultimately in practices that realise the aspiration to democratic and humanist ideals and planetary justice.

\section{References}

Hurt, S. R. 2020. "Washington Consensus”. Encyclopedia Britannica, May 27, 2020. Accessed April 7, 2021. https://www.britannica.com/topic/Washington-consensus.

Klein, N. 2008. The Shock Doctrine: The Rise of Disaster Capitalism. London: Picador. 